\title{
Automated quantification of Epstein-Barr virus in whole blood for post-transplant lymphoproliferative disorders monitoring
}

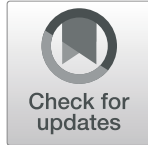

\author{
Maud Salmona ${ }^{1,2^{*}}$ D, Karl Stefic ${ }^{2,3}$, Nadia Mahjoub ${ }^{2}$, Flore Sicre de Fontbrune ${ }^{4}$, Sarah Maylin², François Simon ${ }^{1,2}$, \\ Catherine Scieux ${ }^{1,2}$, Gérard Socié ${ }^{1,4}$, Marie-Christine Mazeron ${ }^{1,2}$ and Jérôme LeGoff ${ }^{1,2}$
}

\begin{abstract}
Background: Standardized and sensitive assays for Epstein Barr Virus (EBV) are needed to define universal cutoff for treatment initiation in allogeneic hematopoietic stem cells transplant recipients. In a context of accreditation and the availability of EBV international standard, we evaluated the Abbott RealTime EBV (RT) assay for EBV quantification in whole blood.
\end{abstract}

Methods: The RT assay was compared on 282 prospective clinical samples with the Artus EBV PCR Kit V1 assay (V1) and we analyzed the kinetics of EBV load in 11 patients receiving rituximab treatment.

Results: The estimated limit of detection was $88 \mathrm{IU} / \mathrm{mL}$. The assay was linear $\left(r^{2}=0.9974\right)$ in the range of all samples tested (100 to 1,000,000 IU/mL). Intra-assay coefficients of variation (CV) ranged between 0.35 and 1.35\%, and inter-assay CV between 3.40 and $4.5 \%$. On samples above the limit of quantification, the two assays were strongly correlated. EBV RT values were on average $0.30 \log _{10} \mathrm{IU} / \mathrm{mL}$ lower than those measured with the V1 assay. In patients treated with rituximab, the RT assay remained positive in 5 patients at the time it dropped below undetectable levels with the V1 assay.

Conclusions: In conclusion, the RT assay is a reliable assay for EBV load in whole blood. Its sensitivity will enable to estimate the kinetics of EBV load and the impact of treatments to control EBV reactivations.

Keywords: EBV, Quantitative PCR, Hematopoietic stem cell transplant, Monitoring , Rituximab

\section{Background}

Epstein Barr Virus (EBV) is a member of the Herpesviridae family. It is estimated that this ubiquitous virus infects more than $90 \%$ of the world's population [1]. After infection, EBV establishes a life-long persistent and latent infection in B lymphocytes. EBV is the causative agent of infectious mononucleosis and is associated with different hematological and epithelial malignancies $[2,3]$. In immunocompromised patients, especially allogeneic hematopoietic stem cell (HSCT) or solid-organ transplant recipients, EBV is associated with post-transplant lymphoproliferative disorders (PTLD) $[4,5]$.

\footnotetext{
* Correspondence: maud.salmona@aphp.fr

${ }^{1}$ Université de Paris Diderot, INSERM U976, Paris, France

${ }^{2}$ Laboratoire de Microbiologie, Hôpital Saint-Louis, APHP, Paris, France

Full list of author information is available at the end of the article
}

Quantification of EBV DNA load in blood is used to identify patients at risk of PTLD [6-8] and EBV DNA levels are considered to start preemptive therapies, including lowering immunosuppressants and administering anti-CD20 monoclonal antibodies, such as rituximab. As EBV DNA load in blood is taken into account for preemptive strategies, accurate and reliable quantification is necessary for the management of patients after transplant [9-13]. However, no universal quantitative cutoff of EBV DNA load to start preemptive treatment has been defined yet. Furthermore, only few studies describe the dynamics of EBV DNA load after rituximab injection [14] .

Results of measurements of EBV DNA loads performed with commercially available assays might differ significantly, particularly according to the extraction method used, which is a source of variability with whole 
blood (WB) [15]. Several studies have reported significant inter-laboratory variation in EBV DNA quantification both in whole blood and plasma samples [16-18].

The determination of a consensual quantitative threshold requires standardization between techniques. In this context, there is a trend for the use of tests approved by regulation authorities, in particular IVD/CE labeled in Europe or FDA approved commercial assays in the USA, and automated techniques [15-21].

Furthermore, since 2010, French national regulations of clinical laboratories require that all the biological assays must be accredited according to the International Standard ISO 15189 [22]. In order to harmonize results and overcome the variability between laboratories, the World Health Organization (WHO) Expert Committee on Biological Standardization established recently the first international standard (IS) for EBV for nucleic acid amplification techniques [23]. Reporting EBV DNA quantification in international unit (IU) is now recommended and industrials develop their assays according to this international standard.

In this study, we performed an evaluation of the IVD/ CE labeled Real-time EBV assay Abbott which includes a fully automated extraction and amplification of EBV DNA from whole blood on the m2000 Real-time systems according to the ISO 15189 recommendations. Clinical samples were tested and the results compared to those obtained with the Artus EBV kit V1 on the m2000 RealTime system [20] that Abbott commercialized before the development of their own assay. We also report the kinetics of EBV load in HSCT patients receiving rituximab therapy.

\section{Materials and methods \\ Standard and clinical samples Ethical considerations}

The study was carried out in accordance with the Declaration of Helsinki. This study was a non-interventional study with no addition sampling to usual procedures. Biological material and clinical data were obtained only for standard viral diagnostic following physicians' prescriptions (no specific sampling, no modification of the sampling protocol). Data analyses were carried out using an anonymized database. According to the French Health Public Law (CSP Art L 1121-1.1), such protocol was exempted from informed consent application.

\section{Clinical samples}

Leftover EDTA K2 tube (BD Vacutainer ${ }^{\circ}$ ) samples sent to the Virology unit of Saint Louis Hospital for EBV monitoring were used in this study. A total of 282 whole blood (WB) specimens received in the laboratory for EBV load quantification were collected from 196 patients including 95 hematopoietic stem cell transplant recipients, 22 kidney transplant recipients, 29 patients with immunological or heamatological diseases, 27 patients from general medicine, $10 \mathrm{HIV}$ infected patients, 9 patients from intensive care unit and 4 patients hospitalized in infectious disease department. The clinical samples were selected prospectively and retrospectively from aliquots frozen at $-80^{\circ} \mathrm{C}$. All clinical consecutive whole blood samples received for EBV quantification within 7 days (124) were tested with the two assays. In order to obtain sufficient positive samples to enable a correlation analysis of EBV loads between the two assays, additional positive whole blood samples were selected retrospectively within 8 months. The samples were tested in separate runs both with the Abbott RealTime EBV assay (RT assay) and EBV PCR Kit V1 assay (V1 assay). Furthermore, 75 additional frozen samples at $-80^{\circ} \mathrm{C}$ of 11 HSCT recipients were tested in order to analyze EBV DNA kinetics after rituximab injection in the two quantitative real time PCR assays.

\section{AcroMetrix ${ }^{\mathrm{TM}} E B V$ controls high and low}

Thermo Scientific ${ }^{\mathrm{Tx}}$ AcroMetrix ${ }^{\mathrm{Tn}}$ EBV low positivecontrol (catalog number 961230, lot 513,101) and highpositive-control (catalog number 961231, lot 417,503) were used for analytical evaluation of RT assay. The manufacturer's instructions mentioned that expected results when using the AcroMetrix ${ }^{\text {Tx }}$ EBV Low and High controls must be established by the end user for their particular EBV DNA assay.

\section{QCMD}

The Quality Control for Molecular Diagnosis (QCMD) 2016 EBV WB challenge 1 and 2 and 2017 EBV WB challenge 1 and 2 proficiency panels were composed of 5 frozen WB samples. Expected values correspond to mean consensus $\left(\log _{10} \mathrm{IU} / \mathrm{mL}\right)$ calculated from data returned by participants from different laboratories after removing outliers.

\section{WHO international standard}

The first WHO international standard for EBV for nucleic acid amplification techniques (National Institute for Biological Standards and Control NIBSC code 09/ 260; Potters Bar, Hertfordshire, Great Britain) is a lyophilized whole virus preparation of the EBV B95-8 strain (type 1). The material has been assigned a concentration of $5 \times 10^{6} \mathrm{IU} / \mathrm{mL}$ when reconstituted in $1 \mathrm{~mL}$ of nuclease-free water.

\section{Quantitative real time PCR assays}

The quantification of EBV in WB was carried out on the Abbott m2000 platform for the two assays. This platform includes the m2000 sp. instrument for automated 
extraction of DNA and the m2000 rt. instrument for real-time PCR of series of 48 samples.

\section{Abbott RealTime EBV assay (RT assay)}

The amplification target is a highly conserved region of the BLLF1 gene which encodes the gp350/220 envelope glycoprotein. The Abbott RealTime EBV assay (Abbott Molecular Inc., Des Plaines, IL, USA) uses three reagent kits, the amplification reagent kit, the calibrator kit for the standard curve and the control kit for external control. An internal control is also supplied to check the overall internal process, including DNA extraction and possible PCR inhibition. Extraction of DNA was done on the m2000sp system. DNA extraction was performed from $300 \mu \mathrm{L}$ of WB and eluted in $250 \mu \mathrm{L}$. Extraction was followed by automated addition of $25 \mu \mathrm{L}$ of master mix and $35 \mu \mathrm{L}$ of purified DNA into the PCR plate. In each run, one negative control and two positive controls (Low and High) were included. Two calibrators (A and B) were used to determine the standard curve. The results are expressed in $\mathrm{IU} / \mathrm{mL}$. Manufacturer lower limit of quantification (LLQ) is reported as $150 \mathrm{IU} / \mathrm{mL}$ and limit of detection (LOD) as $115 \mathrm{IU} / \mathrm{mL}$.

\section{Artus EBV PCR kit V1 assay (V1 assay)}

EBV DNA quantification with the Artus EBV PCR Kit V1 assay (Qiagen, MD, USA, previously commercialized by Abbott Molecular) was also performed on the m2000 platform in batches of 48 tests. The PCR amplification reagent targets a conserved region within the gene coding for Epstein Barr virus Nuclear Antigen (EBNA1). The EBV PCR Kit V1 includes an internal control to check the overall process including DNA extraction and possible PCR inhibition. Automated DNA extraction and PCR reaction set up were performed on the Abbott $m 2000 s p$ instrument. Briefly, DNA was purified from $300 \mu \mathrm{L}$ of WB and eluted in $250 \mu \mathrm{L}$. The EBV quantification was performed with $20 \mu \mathrm{L}$ of purified DNA. Sealed PCR plates were loaded on the Abbott m2000rt instrument for real-time PCR. Four calibrators (QS1, QS2, QS3 and QS4) were used to establish a calibration curve. Every run included one low calibrator (QS3). The results were expressed in copies $/ \mathrm{mL}$. For comparison with the RT assay, conversion factor previously calculated [20] was used to obtain IU/mL. The LLQ of the assay was 1000 copies $/ \mathrm{mL}$ corresponding to $310 \mathrm{IU} / \mathrm{mL}$.

\section{Quantitative real time PCR assays interpretation}

For both assays, the results were classified as follows: target not detected, target detected but not quantifiable $(<$ LLQ) and target detected and quantifiable (>LLQ and in the range of linearity).

\section{Analytical performances of the Abbott RealTime EBV} assay

All dilutions were performed in EBV negative whole blood.

\section{Limit of detection}

The LOD was estimated by using serial dilutions of the WHO international standard at expected value of 500 , 100 and $20 \mathrm{IU} / \mathrm{mL}$. Each dilution was tested 10 times. The LOD is defined as the EBV DNA concentration detected with a probability of $95 \%$ or more.

\section{Assay linearity}

The assay linearity was verified with dilutions of a highly EBV DNA positive sample in EBV negative WB at expected value of 1,000,000,100,000,10,000, 1000 and $100 \mathrm{IU} / \mathrm{mL}$. Each dilution was quantified with the RT assay 3 times and the mean EBV concentration of each sample was calculated.

\section{Repeatability}

The repeatability was determined with the AcroMetrix ${ }^{\text {TM }}$ EBV Plasma Control High (4.76 $\log _{10} \mathrm{IU} / \mathrm{mL}$ ) and two EBV DNA positive WB clinical samples (7.20 $\log _{10} \mathrm{IU} /$ mL - "Blood High"- and $4.09 \log _{10}$ IU/mL - "Blood Low" quantified with Abbott RealTime EBV assay). Ten replicates of each sample were tested in the same run. For each sample, intra assay coefficient of variation (CV) was estimated.

\section{Reproducibility}

The reproducibility was determined with the AcroMetrix $^{\mathrm{Tm}}$ EBV Plasma Control High and Low. Sixteen replicates of AcroMetrix High and Low were tested on a period of 16 days by four different operators. For each sample, inter assay CV was estimated.

\section{Cross-contamination}

A panel of 30 samples consisting of alternate phosphate buffered saline as negative samples and High-load EBV DNA WB $\left(\right.$ mean $\left.=4.29 \log _{10} \mathrm{IU} / \mathrm{mL}\right)$ were assayed on the three $\mathrm{m} 2000$ platforms.

\section{Statistical analysis}

Concordance on qualitative results between the RT assay and the V1 assay was established by Cohen's kappa statistic. The evaluation of quantitative correlation between the two assays included results positive in both and was estimated by using linear regression analysis and BlandAltman plots. Statistical analysis was performed using GraphPad Prism6 software [24]. Differences were considered statistically significant at $p$-values below 0.05 . 


\section{Results}

Analytical performances of the Abbott RealTime EBV assay

The LOD was estimated by using 10 replicates for the three concentrations (500, 100 and $20 \mathrm{IU} / \mathrm{mL}$ ) as shown in Table 1 . The RT assay detected all replicates at $100 \mathrm{IU} / \mathrm{mL}$. Probit analysis of the data predicted a LOD at $88 \mathrm{IU} / \mathrm{mL}$. The assay was linear $\left(\mathrm{r}^{2}=0.9974\right)$ in the range of all samples tested $(1,000$, 000 to $100 \mathrm{IU} / \mathrm{mL}$ ). Intra assay $\mathrm{CV}$, determined on 10 replicates, were $1.35,0.35$ and $1.33 \%$ at the mean value of $4.80 \log _{10} \mathrm{IU} / \mathrm{mL}$ (CI 95 4.75-4.84, AcroMetrix high), $7.30 \log _{10} \mathrm{IU} / \mathrm{mL}$ (CI 95 7.28-7.32, Blood high) and $4.20 \log _{10} \mathrm{IU} / \mathrm{mL}$ (CI95 4.159-4.239, Blood low). Inter assay $\mathrm{CV}$, determined on 16 replicates were $4.5 \%$ at the mean value of $3.61 \log _{10} \mathrm{IU} / \mathrm{mL}$ (CI $953.52-3.69)$ and $3.40 \%$ at the mean value of 4.98 $\log _{10} \mathrm{IU} / \mathrm{mL}$ (CI 95 4.89-5.07). Cross-contamination assays with a panel of 30 negative and highly positive alternate samples did not show any positive result in negative sample on the three $\mathrm{m} 2000$ platforms.

\section{Results from the QCMD EBV proficiency panels}

For quantitative analysis, our results were compared to the consensus mean and standard deviation calculated from all the data returned by the participants to the QCMD EBV proficiency panels. Differences between measured and expected values ranged from 0.254 $(16 \mathrm{C} 1-05)$ to $-0.443 \log _{10} \mathrm{IU} / \mathrm{mL}(16 \mathrm{C} 1-02)($ median $=$ $0.051 \log _{10} \mathrm{IU} / \mathrm{mL}$ ) with a correlation coefficient calculated on positive values of $0.8594(p=0.0002)$. EBV DNA was not detected in the negative QCMD EBV samples (16C1-03 and 16C2-03) and in the educational QCMD samples 16C1-04, 16C2-04 and 17C1-05 (respectively $2.389,2.430$ and $2.597 \log _{10} \mathrm{IU} / \mathrm{mL}$ ). EBV DNA was below the limit of quantification in the educational QCMD 17C1-02(2.457 $\left.\log _{10} \mathrm{IU} / \mathrm{mL}\right)$ (Table 2).

\section{Comparison of the Abbott RealTime EBV and EBV PCR kit V1}

A total of 282 WB clinical samples was analyzed using the two assays (Table 3). By using RT assay, DNA EBV was detected in 196 samples of which 176 were quantified above the LLQ value. With the V1 assay, EBV DNA

Table 1 Lower limit of detection (LOD) of the Abbott RealTime EBV assay for whole blood

\begin{tabular}{llll}
\hline $\begin{array}{l}\text { Expected value (IU/ } \\
\mathrm{mL})\end{array}$ & $\begin{array}{l}\text { No. of } \\
\text { replicates }\end{array}$ & $\begin{array}{l}\text { Mean value (IU/ } \\
\mathrm{mL})\end{array}$ & $\begin{array}{l}\text { Detection rate } \\
(\%)\end{array}$ \\
\hline 500 & 10 & 1239 & 100 \\
100 & 10 & 328 & 100 \\
20 & 10 & 73 & 60 \\
\hline
\end{tabular}

The LOD was estimated by using serial dilutions of WHO international standard in whole blood was detected in 199 samples of which 173 were quantified above the LLQ value. One hundred eighty-six and 161 samples were respectively detected positive and quantified with both assays. The two assays showed a good agreement of $91.84 \%$ with a Kappa index of 0.81 .

Results between the two techniques were discordant for 23 samples (8\%). Discrepancies were observed mainly for samples with a low viral load. Thirteen samples were detected only with V1 assay (DNA load below the LLQ for 9 samples and at 2.59, 2.61, 2.64 and $2.66 \log _{10} \mathrm{IU} /$ $\mathrm{mL}$ for the four other samples) and 10 samples were detected only with RT assay (DNA load below the LLQ for 7 samples and at 2.18, 2.19 and $2.51 \log _{10} \mathrm{IU} / \mathrm{mL}$ for the three other samples).

The analysis of the 161 samples quantified by both assays showed a $\mathrm{r}^{2}$ of 0.8600 between RT and V1 assay $(p<0.0001)$ (Fig. 1). Viral load values measured with the RT assay were on average $0.30 \log _{10} \mathrm{IU} / \mathrm{mL}$ (IC95 0.25-0.34) lower than those measured with the $\mathrm{V} 1$ assay $(p<0.0001)$.

Bland-Altman analysis was used to determine the limit of agreement between the two assays. The mean bias was 0.29 and $95 \%$ limits of agreement ranging from 0.30 to 0.89 . Ten samples were outside the $95 \%$ limits of agreement (Fig. 2). Among the 161 samples quantified by both assays, only one sample differed more than 0.5 $\log _{10} \mathrm{IU} / \mathrm{ml}$ between the two assays $\left(5.11 \log _{10} \mathrm{IU} / \mathrm{mL}\right.$ with $\mathrm{V} 1$ assay and $5.63 \log _{10} \mathrm{IU} / \mathrm{mL}$ with RT assay).

The internal controls included in both test systems were detected within the expected range in all samples.

\section{Kinetics of EBV DNA in WB in 11 HSCT after rituximab injection measured with both assays}

In order to further analyze the correlation between the two assays we compared the viral load kinetics for 11 HSCT recipients who had at least three successively positive samples and received rituximab. Our local practice recommended starting rituximab when EBV load in blood rose above $3.49 \log _{10} \mathrm{IU} / \mathrm{mL} \log _{10}$ with V1 assay after consideration of patient's risk factors. Number of doses varied according the kinetics of EBV loads and biological and clinical parameters. As shown in Fig. 3, the profiles of the two assays were very similar for every patient and variations were always in the same direction. With the use of RT assay, EBV load was considered still positive in 5 patients at the time it dropped below undetectable levels with V1 assay. This may help to better estimate the kinetics of EBV load and the impact of treatments to control EBV reactivations. The median number of doses of rituximab was two. All patients responded to rituximab with a median EBV DNA load decrease after the first dose of $0.42 \log _{10} \mathrm{IU} / \mathrm{mL} /$ day (range: 0.69 to $-0.06 \log _{10} \mathrm{IU} / \mathrm{mL} /$ day; EBV load values with RT assay). In nine patients (\#2, \#3, \#5-11), a 
Table 2 Quantification of EBV DNA with Abbott RealTime EBV assay in QCMD 2016 EBV samples

\begin{tabular}{|c|c|c|c|c|c|c|c|}
\hline & & Sample & QCMD results & & & RT EBV assay result & \\
\hline & & & $\begin{array}{l}\text { EBV load } \\
\left(\log _{10} \text { copies/mL) }\right.\end{array}$ & $n$ & Range & $\begin{array}{l}\text { EBV load } \\
\left(\log _{10} \text { copies } / \mathrm{mL}\right)\end{array}$ & $\begin{array}{l}\text { Delta } \log _{10} \\
\text { (RT-QCMD) }\end{array}$ \\
\hline 2016 panel 1 & $C$ & $16 C 1-01$ & 3.673 & $52 / 52$ & $2.937-4.772$ & 3.819 & 0.146 \\
\hline & $C$ & $16 C 1-02$ & 3.200 & $48 / 52$ & $1.398-4.094$ & 2.757 & -0.443 \\
\hline & $C$ & $16 C 1-03$ & ND & N/A & N/A & ND & ND \\
\hline & $E$ & $16 C 1-04$ & 2.389 & $37 / 52$ & $1.000-3.732$ & ND & ND \\
\hline & $C$ & $16 C 1-05$ & 3.673 & $52 / 52$ & $3.247-4.580$ & 3.927 & 0.254 \\
\hline 2016 panel 2 & $C$ & $16 C 2-01$ & 4.144 & $53 / 53$ & $3.511-4.710$ & 4.096 & -0.048 \\
\hline & $C$ & $16 C 2-02$ & 2.949 & $49 / 53$ & $2.068-3.781$ & 3.074 & 0.125 \\
\hline & $C$ & $16 C 2-03$ & ND & N/A & N/A & ND & ND \\
\hline & $E$ & $16 C 2-04$ & 2.430 & $31 / 53$ & $1.079-3.534$ & ND & ND \\
\hline & $C$ & $16 C 2-05$ & 3.684 & $53 / 53$ & $3.117-4.302$ & 3.539 & -0.145 \\
\hline 2017 panel 1 & $C$ & $17 C 1-01$ & 4.112 & $46 / 47$ & $3.002-5.105$ & 3.941 & -0.171 \\
\hline & $E$ & $17 C 1-02$ & 2.457 & $30 / 47$ & $1.613-3.182$ & Pos NQ & ND \\
\hline & C & $17 C 1-03$ & 4.103 & $46 / 47$ & $3.548-5.240$ & 3.994 & -0.109 \\
\hline & C & $17 C 1-04$ & 3.573 & $44 / 47$ & $2.444-4.454$ & 3.435 & -0.138 \\
\hline & $E$ & $17 C 1-05$ & 2.597 & $27 / 47$ & $1.519-3.872$ & ND & ND \\
\hline 2017 panel 2 & C & $17 C 2-01$ & 4.220 & $50 / 50$ & $3.609-4.837$ & 4.179 & -0.041 \\
\hline & $\mathrm{C}$ & $17 C 2-02$ & 3.661 & $50 / 50$ & $3.029-4.754$ & 3.497 & -0.164 \\
\hline & - & $17 C 2-03$ & Excluded & & & Excluded & ND \\
\hline & $C$ & $17 C 2-04$ & 3.660 & $49 / 50$ & $3.208-4.089$ & 3.609 & -0.051 \\
\hline & $C$ & $17 C 2-05$ & 3.009 & $47 / 50$ & $2.107-3.877$ & 3.079 & 0.07 \\
\hline
\end{tabular}

Consensus $\log _{10}$ virus concentrations were calculated as the mean values reported from positives datasets $(n)$ submitted by clinical laboratories ND, EBV DNA was not detected

Pos NQ, EBV DNA was detected but not quantified

C core, E educational

Excluded, panel member was excluded of the QCMD report

delta $\log _{10}, \log _{10}$ copies/ml difference between the RT assay and QCMD consensus

significant decrease of EBV load ( $>0.5$ log; EBV load values with $\mathrm{RT}$ assay) was observed after the first dose while it remained stable in two patients (\#1, \#4). After a median follow-up of 517 days (range: 82 to 1468 days) none of them had developed a PTLD.

\section{Discussion}

Sensitive and reproducible EBV DNA quantification in blood is critical for preemptive treatment initiation and

Table 3 Comparison Of V1 And Rt Ebv Assays On 282 Whole Blood Samples

\begin{tabular}{llllll}
\hline & & \multicolumn{3}{l}{ RT EBV assay } & \\
\cline { 3 - 6 } & & Quantified & Detected & Not Detected & Total \\
\hline \multirow{2}{*}{ 1 assay } & Quantified & 161 & 8 & 4 & 173 \\
& Detected & 12 & 5 & 9 & 26 \\
& Not Detected & 3 & 7 & 73 & 83 \\
& Total & 176 & 20 & 86 & 282 \\
\hline
\end{tabular}

Quantified: EBV DNA detected and above the limit of quantification of the assay

Detected: EBV DNA detected and below the limit of quantification of the assay monitoring. The medical community involved in the management of HSCT patients needs consensual threshold values to start treatments. To achieve this goal, the first step is the creation of an international standard for the quantification of EBV DNA. We have tested an automated assay for the quantification of EBV in whole blood using the WHO EBV international standard. In addition to the international standard we also tested QCMD panels to better estimate the accuracy of the assay. We then compared results from this assay with results from a former real-time quantitative PCR, a series of clinical samples and the prospective follow-up of EBV load in patients who received a therapy with rituximab for EBV reactivation.

The LOD estimated in our study $(88 \mathrm{IU} / \mathrm{mL})$ was close to that defined by the manufacturer $(115.2 \mathrm{IU} / \mathrm{mL}$, 95\%CI 97.6-150.5 IU/mL) who also used WHO EBV international standard for LOD determination. Previous evaluation of this assay by Lee et al. estimated a lower LOD $(48.9 \mathrm{IU} / \mathrm{mL})$ that may be explained by the use of different analytical panels (Qnostic) [25]. The assay was 


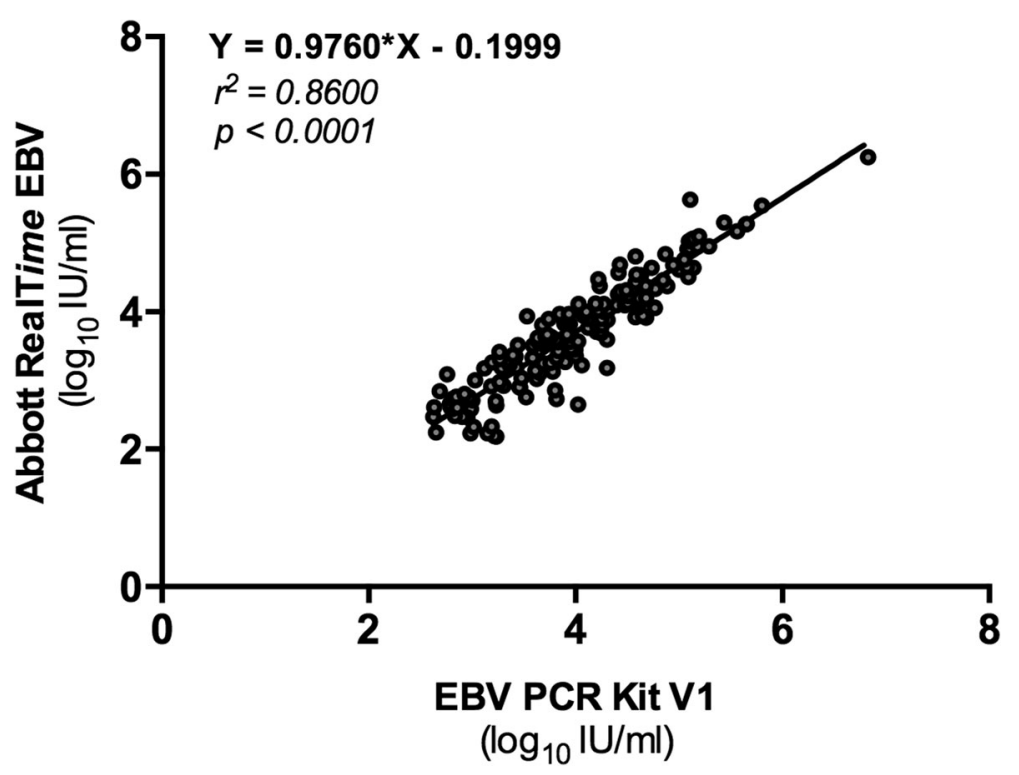

Fig. 1 Correlation plot of EBV DNA load values measured by the two assays. Correlation plot of EBV DNA load values measured by EBV PCR kit V1 and the Abbott RealTime EBV assays for samples quantified with the two assays $(n=161)$. EBV DNA loads are expressed in $\log _{10} \mathrm{IU} / \mathrm{mL}$. For $V 1$ assay, $\log _{10} \mathrm{IU} / \mathrm{mL}$ were calculated from log copies/mL using previously calculated conversion factor

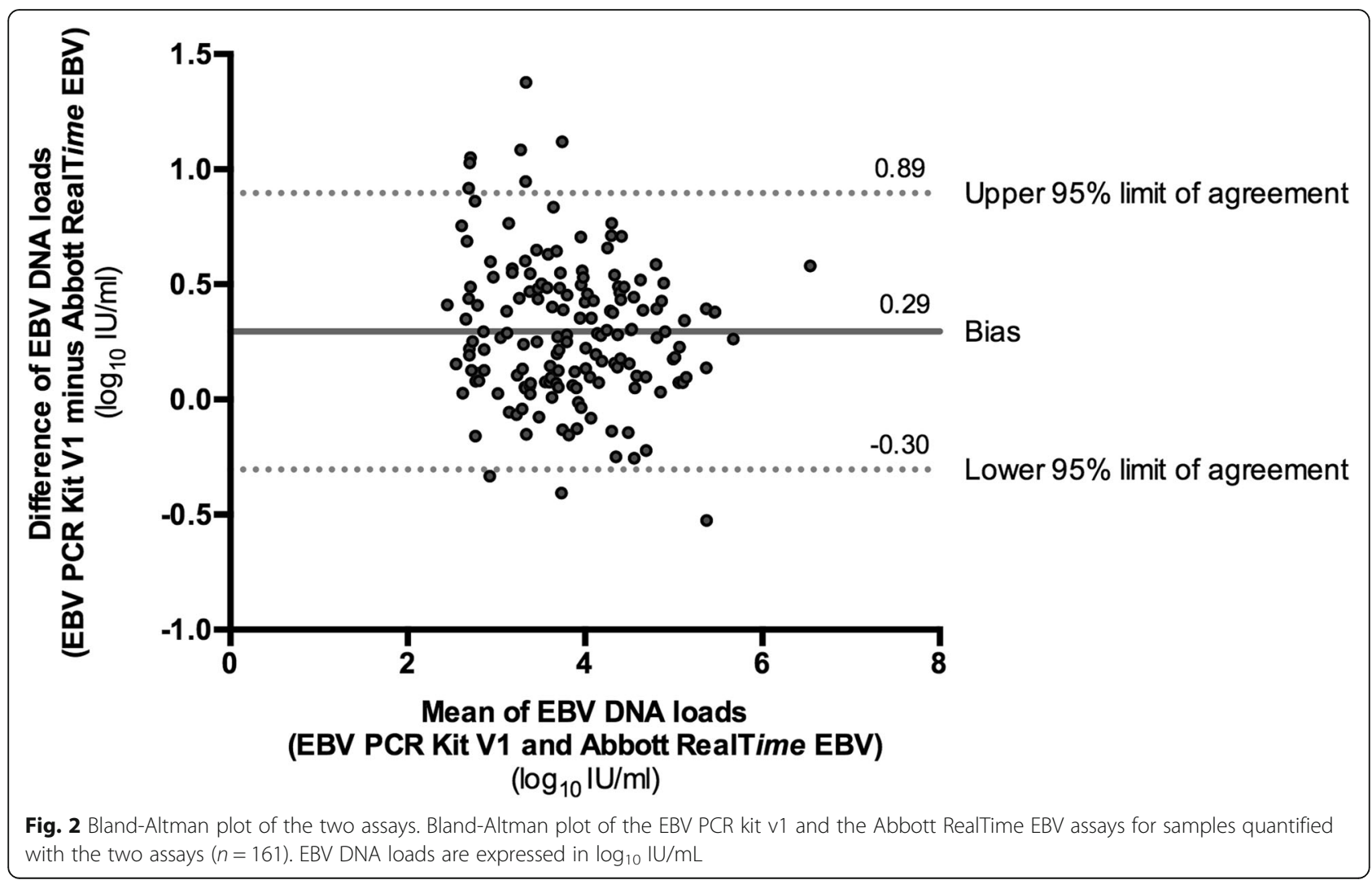




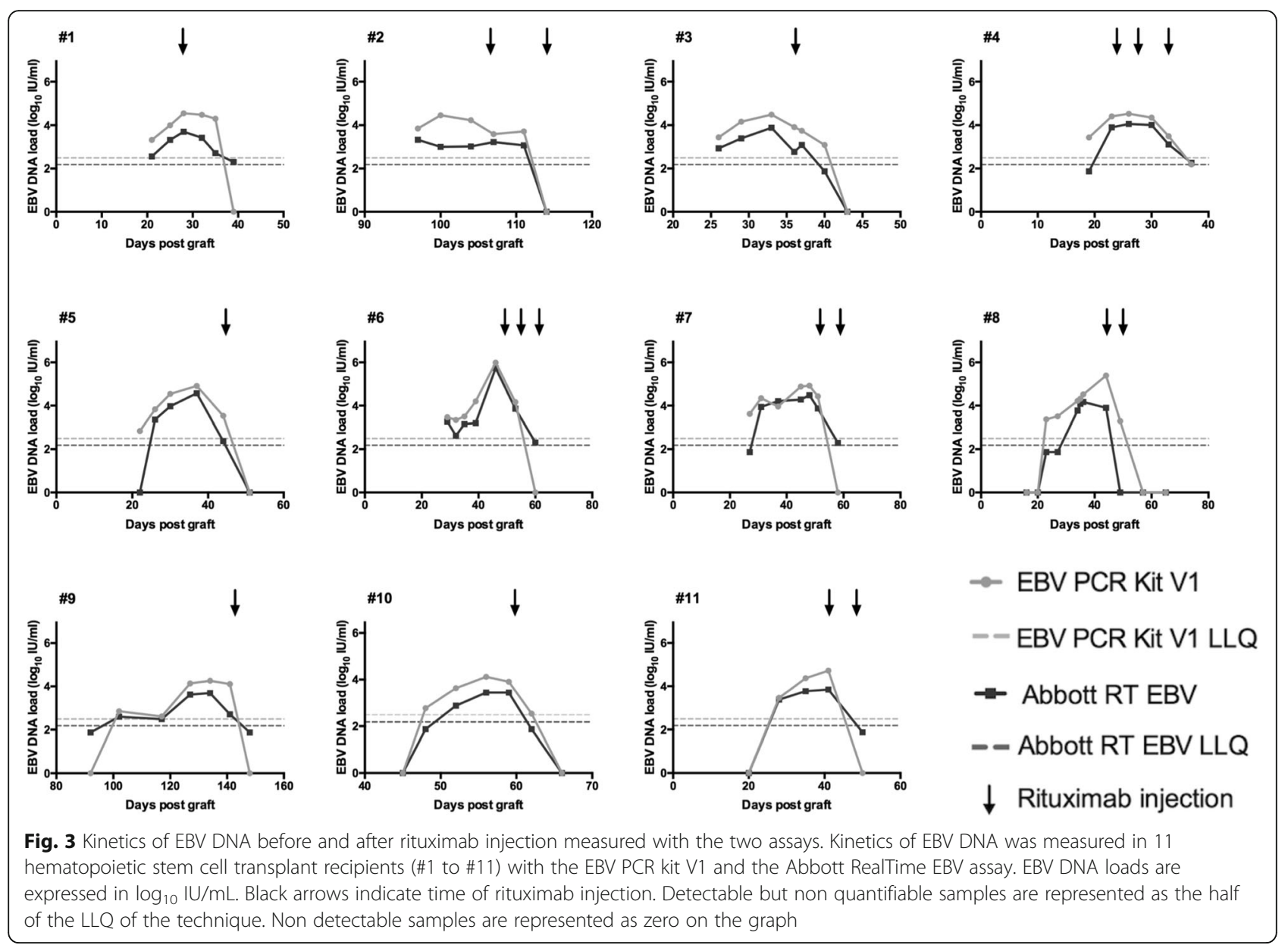

linear in the large range of values $\left(10^{2}\right.$ to $\left.10^{6} \mathrm{IU} / \mathrm{mL}\right)$ that fits with values usually observed in blood samples. The assay was highly reproducible with intra CV below $2 \%$ and inter CV below 5\% which is similar to values previously reported [25]. In addition, the assay enables a complete traceability from sample registration in the laboratory informatics system (LIS) to results transmission from the molecular platform to the LIS. Altogether our results enabled to fulfill criteria to approve RT assay in accordance to international ISO 15189 standard [22].

Four panels of European molecular quality controls (QCMD 2016 and 2017) were tested. RT assay results were correlated with the expected values. Only educational samples with values below $3 \log _{10} \mathrm{IU} / \mathrm{mL}$ were not detected, thus slightly higher than LOD values we found, and found by other studies and those claimed by the manufacturer. In another work, Abbott RealTime EBV run on a different system (maxCycle) detected all EBV positive samples in 2015 and 2016 QCMD panels including those below $3 \log _{10} \mathrm{IU} / \mathrm{mL}$ [26].

The comparison of RT assay with the V1 assay we used in clinical practice, on clinical samples, showed similar results. Quantitative values of positive samples were highly correlated. Eight percent of samples were discrepant and corresponded to low EBV load values. Viral load values measured with the RT assay were on average $0.30 \log _{10} \mathrm{IU} / \mathrm{mL}$ lower than those measured with the V1 assay suggesting that threshold values for therapeutic management might be adapted. Previously, comparison between the same two assays gave similar results on plasma samples collection [21]. Vinuesa et al. study also found a significant correlation between assays on 60 plasma specimens quantifiable by both assays $\left(r^{2}=0.669 ; p=<0.0001\right)$ but a non-significant difference between the two assays $(0.07 \log \mathrm{UI} / \mathrm{mL})$. A seemingly higher difference between the two assays in our series may reflect the higher complexity for extracting whole blood than plasma and may account also for the higher number of samples tested in our work.

The comparison of both assays in the follow-up of patients with EBV loads requiring rituximab treatment showed stackable curves. Results of the patients' follow-up suggest also that the RT assay gave a better estimation of control of EBV reactivation as it remained positive longer than V1 assay after rituximab injection. However, in these patients, a change in rituximab treatment due to the use 
of RT assay instead of V1 assay seems unlikely. In our institution, a follow-up of the patients was made during several weeks after the routine implementation of the Abbott assay and a new therapeutic threshold was defined in agreement with the clinicians and based on our local experience. Higher sensitivity might be useful for EBV halflife determination with current treatments and future therapies and thus might help in defining treatment efficacy. Such a technique and others in the market using international standard should now be used for multicenter studies to define a clinical threshold for preemptive therapies that might help to optimize rituximab treatment, considering its potential side-effects.

\section{Conclusion}

In conclusion, the RT assay is a reliable assay for EBV load in whole blood. Its sensitivity will enable to estimate the kinetics of EBV load and the impact of treatments to control EBV reactivations.

\section{Abbreviations \\ CV: Coefficients of Variation; EBV: Epstein Barr Virus; HSCT: Hematopoietic Stem Cell Transplant; IS: International Standard; IU: International Unit; LLQ: Lower Limit of quantification; LOD: Limit of Detection; PTLD: Post Transplant Lymphoproliferative Disorders; QCMD: Quality Control for Molecular Diagnosis; RT assay: EBV RealTime Abbott assay; V1 assay: EBV PCR Kit V1 Abbott assay; WB: Whole Blood}

\section{Acknowledgements}

Not applicable.

\section{Authors' contributions}

CS, MCM, SM, GS and JLG designed the study. MS, KS and NM performed the experiment and data analysis. MS wrote the manuscript. JLG, FSF and FS revised the manuscript. All authors read and approved the final manuscript.

\section{Funding}

Not applicable.

\section{Availability of data and materials}

The datasets analysed are available from the corresponding author on request.

\section{Ethics approval and consent to participate}

The study was carried out in accordance with the Declaration of Helsinki. This study was a non-interventional study with no addition sampling to usual procedures. Biological material and clinical data were obtained only for standard viral diagnostic following physicians' prescriptions (no specific sampling, no modification of the sampling protocol). Data analyses were carried out using an anonymized database. According to the French Health Public Law (CSP Art L 1121-1.1), such protocol was exempted from informed consent application.

\section{Consent for publication}

Not applicable.

\section{Competing interests}

JLG AND FS declare Consultancies, honoraria and expert testimony with Abbott laboratories. All other authors declare that they have no competing interest.

\section{Author details}

${ }^{1}$ Université de Paris Diderot, INSERM U976, Paris, France. ${ }^{2}$ Laboratoire de Microbiologie, Hôpital Saint-Louis, APHP, Paris, France. ${ }^{3}$ Université de Tours,
INSERM U1259, Tours, France. ${ }^{4}$ Hematology and Transplantation Unit, Hôpital Saint-Louis, APHP, Paris, France.

Received: 16 October 2019 Accepted: 20 January 2020

Published online: 03 February 2020

\section{References}

1. Williams $H_{1}$ Crawford DH. Epstein-Barr virus: the impact of scientific advances on clinical practice. Blood. 2006;107:862-9.

2. Abu-Elmagd KM, Mazariegos G, Costa G, Soltys K, Bond G, Sindhi R, et al. Lymphoproliferative disorders and de novo malignancies in intestinal and multivisceral recipients: improved outcomes with new outlooks. Transplantation. 2009:88:926-34.

3. Vetsika E-K, Callan M. Infectious mononucleosis and Epstein-Barr virus. Expert Rev Mol Med. 2004;6:1-16.

4. Martinez OM, de Gruijl FR. Molecular and immunologic mechanisms of cancer pathogenesis in solid organ transplant recipients. Am J Transplant Off J Am Soc Transplant Am Soc Transpl Surg. 2008:8:2205-11.

5. Snow AL, Martinez OM. Epstein-Barr virus: evasive maneuvers in the development of PTLD. Am J Transplant Off J Am Soc Transplant Am Soc Transpl Surg. 2007;7:271-7

6. Preiksaitis JK, Keay S. Diagnosis and management of posttransplant lymphoproliferative disorder in solid-organ transplant recipients. Clin Infect Dis Off Publ Infect Dis Soc Am. 2001;33(Suppl 1):S38-46.

7. Stevens SJ, Verschuuren EA, Pronk I, van Der Bij W, Harmsen MC, The TH, et al. Frequent monitoring of Epstein-Barr virus DNA load in unfractionated whole blood is essential for early detection of posttransplant lymphoproliferative disease in high-risk patients. Blood. 2001:97:1165-71.

8. van Esser JWJ, Niesters HGM, van der Holt B, Meijer E, Osterhaus ADME, Gratama JW, et al. Prevention of Epstein-Barr viruslymphoproliferative disease by molecular monitoring and preemptive rituximab in high-risk patients after allogeneic stem cell transplantation. Blood. 2002:99:4364-9.

9. Baiocchi OCG, Colleoni GWB, Caballero OL, Vettore AL, Andrade ALSS, Pestana JOM. Quantification of Epstein-Barr viral load and determination of a cut-off value to predict the risk of post-transplant lymphoproliferative disease in a renal transplant cohort. Haematologica. 2004:89:366-8.

10. Gulley ML, Tang W. Using Epstein-Barr viral load assays to diagnose, monitor, and prevent Posttransplant Lymphoproliferative disorder. Clin Microbiol Rev. 2010;23:350-66.

11. Kwong Y-L, Pang AWK, Leung AYH, Chim C-S, Tse E. Quantification of circulating Epstein-Barr virus DNA in NK/T-cell lymphoma treated with the SMILE protocol: diagnostic and prognostic significance. Leukemia. 2014;28:865-70.

12. Meerbach A, Wutzler P, Häfer R, Zintl F, Gruhn B. Monitoring of Epstein-Barr virus load after hematopoietic stem cell transplantation for early intervention in post-transplant lymphoproliferative disease. J Med Virol. 2008:80:441-54.

13. Ruf S, Behnke-Hall K, Gruhn B, Bauer J, Horn M, Beck J, et al. Comparison of six different specimen types for Epstein-Barr viral load quantification in peripheral blood of pediatric patients after heart transplantation or after allogeneic hematopoietic stem cell transplantation. J Clin Virol Off Publ Pan Am Soc Clin Virol. 2012:53:186-94.

14. Raberahona M, Wackenheim C, Germi R, Carré M, Bulabois C-E, Thiébaut A, et al. Dynamics of Epstein-Barr viral load after hematopoietic stem cell transplantation and effect of preemptive rituximab therapy. Transpl Infect Dis Off J Transplant Soc. 2016:18:889-95.

15. Germi R, Lupo J, Semenova T, Larrat S, Magnat N, Grossi L, et al. Comparison of commercial extraction systems and PCR assays for quantification of Epstein-Barr virus DNA load in whole blood. J Clin Microbiol. 2012;50:1384-9.

16. Abbate I, Zanchetta M, Gatti M, Gabrielli L, Zanussi S, Milia MG, et al. Multicenter comparative study of Epstein-Barr virus DNA quantification for virological monitoring in transplanted patients. J Clin Virol Off Publ Pan Am Soc Clin Virol. 2011;50:224-9.

17. Hayden RT, Hokanson KM, Pounds SB, Bankowski MJ, Belzer SW, Carr J, et al. Multicenter comparison of different real-time PCR assays for quantitative detection of Epstein-Barr virus. J Clin Microbiol. 2008:46:157-63.

18. Preiksaitis JK, Pang XL, Fox JD, Fenton JM, Caliendo AM, Miller GG, et al. Interlaboratory comparison of epstein-barr virus viral load assays. Am J Transplant Off J Am Soc Transplant Am Soc Transpl Surg. 2009;9:269-79. 
19. Hübner M, Bozic M, Konrad PM, Grohs K, Santner Bl, Kessler HH. Analytical and clinical performance of a new molecular assay for Epstein-Barr virus DNA quantitation. J Virol Methods. 2015;212:39-43.

20. Salmona M, Fourati S, Feghoul L, Scieux C, Thiriez A, Simon F, et al. Automated quantification of Epstein-Barr virus in whole blood of hematopoietic stem cell transplant patients using the Abbott m2000 system. Diagn Microbiol Infect Dis. 2016;85:428-32.

21. Vinuesa V, Solano C, Giménez E, Navarro D. Comparison of the artus Epstein-Barr virus (EBV) PCR kit and the Abbott RealTime EBV assay for measuring plasma EBV DNA loads in allogeneic stem cell transplant recipients. Diagn Microbiol Infect Dis. 2017;88:36-8.

22. Schneider F, Maurer C, Friedberg RC. International Organization for Standardization (ISO) 15189. Ann Lab Med. 2017:37:365-70.

23. Fryer JF, Heath AB, Wilkinson DE, Minor PD, Collaborative Study Group. A collaborative study to establish the 1st WHO international standard for Epstein-Barr virus for nucleic acid amplification techniques. Biol J Int Assoc Biol Stand. 2016:44:423-33.

24. Prism - graphpad.com. [cited 2018 Dec 19]. Available from: https://www. graphpad.com/scientific-software/prism/

25. Lee J-S, Yoon M, Kim MJ, Cho SI, Seong M-W, Park SS, et al. Evaluation of the new Abbott real-time EBV assay: fully automated quantification of EBV in whole blood by targeting BLLF1. Diagn Microbiol Infect Dis. 2019:94:135-9.

26. Bontems S, Boreux R, Capraro V, Huynen P, Descy J, Melin P, et al. Evaluation of the Abbott RealTime quantitative CMV and EBV assays using the maxCycle protocol in a laboratory automation context. J Virol Methods. 2019;270:137-45

\section{Publisher's Note}

Springer Nature remains neutral with regard to jurisdictional claims in published maps and institutional affiliations.

Ready to submit your research? Choose BMC and benefit from:

- fast, convenient online submission

- thorough peer review by experienced researchers in your field

- rapid publication on acceptance

- support for research data, including large and complex data types

- gold Open Access which fosters wider collaboration and increased citations

- maximum visibility for your research: over $100 \mathrm{M}$ website views per year

At $\mathrm{BMC}$, research is always in progress.

Learn more biomedcentral.com/submissions 